\title{
KP 排水の活性污泥一凝沈処理における現場管理
}

\section{Operating Experience with Activated Sludge-Coagulating Sedimentation Process of Kraft Mill Effluents.}

\author{
Kiyoshi Kurihara \\ Kishu Mill, Kishu Paper Co., Ltd.
}

はじめに

近年: 紙パルプ座業の排水处理には活性污泥上凝沈 の組み合わせ处理掂が多く採用されているように思ら。 このように热及した装团には, 処理コストが安伍であ るといらことの他に, 紙, 排水は有機性の污濁物質を 含息排水が王であること，こ机が生物的処理に適して いるからであるう。

当工場が KP 排水に活性活泥処理法を採用し，実 運伝に入ったのは胎和 48 年 5 月からで, 過去 3 年余 りの運転経験からようやく活尘污泥の正体をつかんだ ような気がしているところである。

運転管理上，まだ幾多の改善すべき問題を残してい るが，ほぼ湍足すべき处理結果を得ているので，ここ に運転実績等を紿介し，今後の指針となれば幸いであ る。

\section{1. 処理対象排水及び処理方法検討の経過}

パルプ洗浄排水及び抄紙系排水は，46 年当時からす でに加圧浮上処理を行なっていたので，パルプ漂白工 程の排水にしぼって処理方法の榆討を行なった。

当工場の漂白シーケンスは, $\mathrm{C}-\mathrm{E}_{1}-\mathrm{H}-\mathrm{D}_{1}-\mathrm{E}_{2}-\mathrm{D}_{2}$ の 6 段であるが，特に污濁量の多い前 3 段 $\mathrm{C}, \mathrm{E}_{1} . \mathrm{H}$ を 処理対象水とした。

当時，C段の全排水学活性污泥処理している実續は なく有効㙁素の問題から果たして活性污泥処理が適当 かどらか，この点が最も䯚念されるところであった。 しかし，ラボテストにより $\mathrm{E}_{1}$ 排水との組み合わせに よって C 段残有効塩素が $150 \mathrm{ppm}$ までは問題のない
ことがわかった。

当工場の適用される排水規制值は $\mathrm{COD}$ 規制であり， 活性污泥処理だけでは十分でないこと及び脱色ができ ないこと等で，凝集沈殿処理との組み合わせを検討し た。その場合, 活性污泥处理の徭に㠜集沈即処理を行 なった方がよいのか，それともその逆がよいのか処理 コストの面から検討した絬果, 活性污泥の後に凝集沈 殿処理を行なった方が㠜集剂の使用量で約 $30 \%$ 軽減 されることがわかり，しかも同等以上の水質が得られ た。よって，次のフローに決定した。

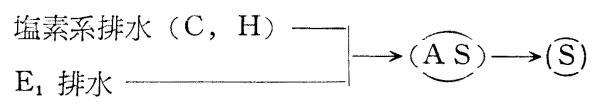

\section{2. 処理設備の概要とフローシート}

設備仕様を表 1 ，フローシートを図 1 に示す。

\section{1 処理水量}

塩䇣系排水 $(\mathrm{C}, \mathrm{H}) \quad 450 \mathrm{t} / \mathrm{h}$

$\mathrm{E}_{1}$ 排水 $\quad 100 \mathrm{t} / \mathrm{h}$ 計 $550 \mathrm{t} / \mathrm{h}$

\section{2 原水の $\mathrm{pH}$ 調整}

廃牽物の有効利用の面から苛性化ドレッグスを塩素 系排水（pH 1.8 2.0）に添加し, $\mathrm{pH} 3$ 3 3.5 にコン トロール（pH 4 以上になるとドレッグスは溶解しな い)。

その後, 中和槽で消石灰を用いて $\mathrm{pH} 6$ 亿 2 段コン トロールしている。この対策により, 中和用消石圧が 節約できる。

\section{3 活性污泥の栄養源}

BOD : N : P は 100:5:1 をめどにしているが, 
原水中に $\mathrm{N}, \mathrm{P}$ が含有しているのでこの 分を加味して添加している。実際の添加量 は $100: 3: 0.05$ 程度である。

\section{4 中和槽及びばっ気槽の消泡}

ばっ気槽で泡だちが激しく, 中和槽で消 泡剂を添加（ $3 \mathrm{ppm}$ 程度）し, 更にばっ 気槽周囲に消泡水配管を設け消泡している。

\section{3. 運転実績}

今までの運転実績を表 2，表 3 亿示す。

\section{1 水 温}

夏期になると原水水温が $40^{\circ} \mathrm{C}$ 近くにも なり, BOD 除去率は低下の傾向にある。 この要因として次の 2 つが考えられる。

・水温上昇による菌体の衰退

・水温上昇による酸素溶解度の低下 $(\mathrm{DO}$ の不足)

これについては原水のクーリング対策が あるが，さして問題にするほどのこともな いので行なっていない。

\section{$3.2 \mathrm{SV}$. MLSS}

SV 20 30\%, SV 1 30 45 と低く, 活性污泥処理 の問題点の 1 つ挙げられているバルキングといった ことも経験したことがない。

$\mathrm{SV}$ が低い理由として, 原水の中和用に苛性化ドレ ッグスを添加している関係で若干のドレッグス不溶解
表 1 設備仕様

\begin{tabular}{|c|c|}
\hline 原 水 槽 & $\begin{array}{l}2,440 \phi \times 2,600 \mathrm{H} \\
\text { 有効実績 } 12 \mathrm{~m}^{3}\end{array}$ \\
\hline 和 & $\begin{array}{l}4,900 \mathrm{~W} \times 5,900 \mathrm{~L} \times 3,600 \mathrm{H} \\
\text { 有効水深 } 3,100 \mathrm{D} \text {, 有效容積 } 75 \mathrm{~m}^{3}\end{array}$ \\
\hline ばっ気槽 & $\begin{array}{l}19,000 \mathrm{~W} \times 3,800 \mathrm{~L} \times 4,545 \mathrm{H} \\
\text { 有効水深 } 4,000 \mathrm{D} \text {, 有効容積 } 2,888 \mathrm{~m}^{3} \\
\text { 表面ばっ気機 } 55 \mathrm{~kW} \times 2 \text { 基 }\end{array}$ \\
\hline 殿 & $\begin{array}{l}20,000 \mathrm{~W} \times 39,000 \mathrm{~L} \times 2,900 \mathrm{H} \\
\text { 有効水深 } 2,000 \mathrm{D} \text {, 有效容積 } 1,560 \mathrm{~m}^{3}\end{array}$ \\
\hline 高速凝集沈殿槽 & $\begin{array}{l}29,000 \phi \times 5,500 \mathrm{H} \\
\text { 有効水深 } 5,000 \mathrm{D} \text {, 有効容積 } 3,300 \mathrm{~m}^{3}\end{array}$ \\
\hline 縮 & $\begin{array}{l}16,000 \phi \times 5,500 \mathrm{H} \\
\text { 有效水深 4,500 D, 有効容積 } 890 \mathrm{~m}^{3}\end{array}$ \\
\hline
\end{tabular}

分が入っているためと考えられる。污泥の沈降性がよ いため沈殿槽におけるキャリオーバーがない反面，ば っ気槽において污泥が沈降しやすくなる。BOD 負荷 (污泥負荷)をもら少し下げて運転したいが，この沈 降の問題から MLSS を現状よりアップすることはむ ずかしく，6,000〜7,000 ppm の簌囲で運転している。

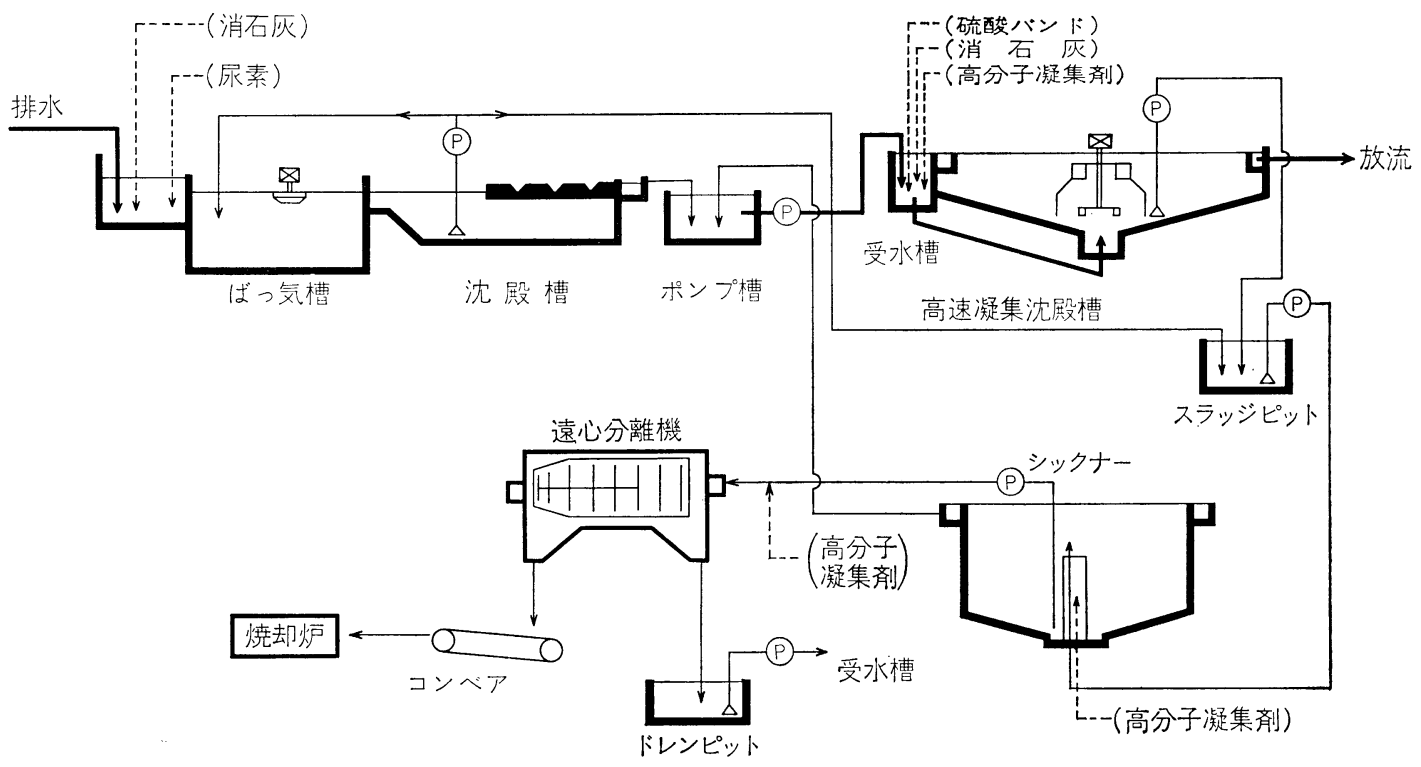

図 1 排水処理設備 (活性污泥+凝集沈殿) 
表 2 水質 実 績

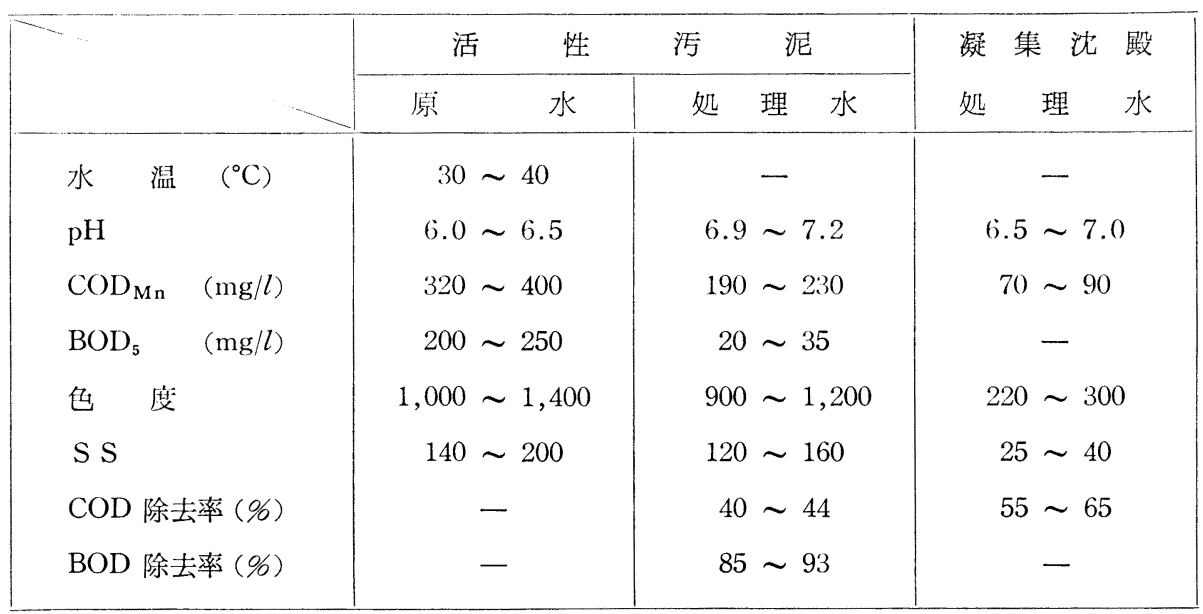

注 1. 色度は湓化白金酸コバルト法による。

2. 凝集沈殿における硫酸バンド添加量 $900 \sim 1,000$ ppm.

\section{4. 長期休転時の污泥管理}

工埸修理日，休日など, 操業停止時の涯 泥管理ほどめんどうなものはない。無負荷 状態でばっ気を続行すると，炏第に自己 (微生物) の估構成物䁈を消化するように なる。いわゆる自己消化におちいる。かと いって, 好気性菌であるだけに長時間酸素 を断つことはできない。もし，ばっ気機を 長時間停止しておくと, 污泥は沈積し, 酸 素欠乏のため嫌気状態になって腐敗し失活 状態になる。

従って, 工場定修等に掞いても排水流入 時の状態を維持してやる必要がある。つま り，排水に含まれる有機物の組成に準じて 他から BOD 源を求め供給してやる必要が ある。しかし, 実際, 他から BOD 源を求 め通常操業時の上らに排水処理を運転するとなると経 済性の面から，また，作業性の面から困難である。

当工場では, 定修時等の長期停止時には次のよ5に 污泥の維持管理を行ない。今まで大きな支障もなく今 日に至っている。

（1）工場停止数日前から余剩污泥の引き抜きを停止し， 污泥の絶対量を增す (MLSS 10,000 ppm をめどに している)。

（2）原水流入が停止したら返送污泥を停止し，処理水 を次のように循環してばっ気槽中の污泥をできるだ
表 3 活性污泥の状況

\begin{tabular}{|c|c|c|}
\hline 水 & $\left({ }^{\circ} \mathrm{C}\right)$ & $28 \sim 38$ \\
\hline BOD 容積負荷 & $\left(\mathrm{kg} / \mathrm{m}^{3}\right.$, 日) & $0.9 \sim 1.1$ \\
\hline BOD 污泥負荷 & (kg/MLSS-kg, 日) & $0.13 \sim 0.18$ \\
\hline DO & $(\mathrm{ppm})$ & $1 \sim 3$ \\
\hline $\mathrm{O}_{2} \mathrm{Rr} \mathrm{B} / \mathrm{A}$ & $(\mathrm{ppm} / \mathrm{h})$ & $80 \sim 150 / 10 \sim 30$ \\
\hline SV & $(\%)$ & $20 \sim 30$ \\
\hline SV 1 & $(\mathrm{cc} / \mathrm{g})$ & $30 \sim 45$ \\
\hline MLSS & $(\mathrm{ppm})$ & $6,000 \sim 7,000$ \\
\hline MLVSS & $(\mathrm{ppm})$ & $4,800 \sim 5,400$ \\
\hline
\end{tabular}

注 1. $\mathrm{O}_{2} \mathrm{Rr} \mathrm{A}$ : 基質無添加酸素吸収速度

$\mathrm{O}_{2} \mathrm{Rr} \mathrm{B}$ : 基質添加酸素吸収速度
け沈殿槽に移す。

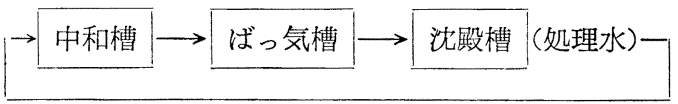

（3）沈殿槽に污泥を移し終われば，返送污泥用ポンプ を利用し，次のようにして沈殿槽内で污泥を滝落と しによりばっ気する。 


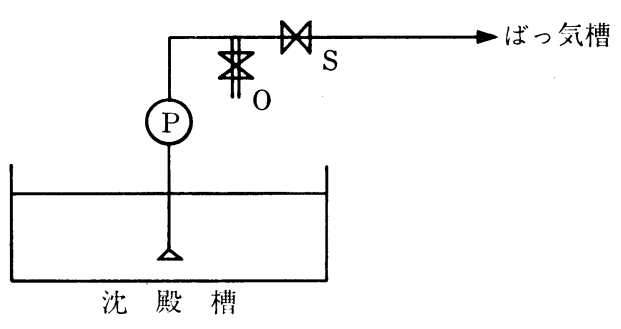

この場合, スクレーパーを運転して置けば沈殿槽底 泥を満遍なくばっ気することができる。しかしこの 対策によっても特に夏期には数日寸ると污泥の一部が 嫌気性となり, 泡の発生が著しくなってスカムが浮い たような状態になる。この場合, 適宜消泡剂を注入し 抑える。また, 毎日, 通常運転時の尿素量の 20 分の 1 程度を栄養剤として投与している。

以上のような沈殿槽において污泥管理するようにし たのは次の理由からである。

当初, ばっ気槽で 2 台のばっ気機を交互に断続運転 し，過ばっ気になるのを避けてきたが，前述したよう に污泥の沈降性がよいために, ばっ気槽底部に污泥が 沈み嫌気性になる。また，一度沈んだ污泥は，再ばっ 気しても浮かないためである。

このよらにして, 冬期ではあったが約 1 力月間運転 した実績がある。この時は途中 2 回にかけて各 3 日間 ばっ気槽に污泥を返し，それぞれ通常 BOD 負荷量の 10 分の 1 程度の黒液を投入したがその効果はあやし い。

原水流入時には一度に全量処理せずに， $\mathrm{O}_{2} \mathrm{Rr}$ （酸 素吸収速度）を測定しながら順次負荷量をアップさせ 6 日間で全量処理とした。その結果,スタートしてから 2 日間の BOD 除去率は低かったが, これは長期停止 中污泥の活性度が低下したといらょうよりも, むしろ 長期停止によるばっ気槽の水温低下（14〜 $15^{\circ} \mathrm{C}$ まで 低下）による方が大きいものと考えており，正常にも どすのに 6 日間を要することもなかったかも知れない。

1 週間程度の休転は何回も経験しているが, 途中基 質（黒液）を投与せずとも十分活性度を維持すること ができ, 2 日目からは全量処理しているが問題はない。 （4）長期停止後の負荷量アップの指標

污泥の活性度をみる指標として BOD 除去率より判 断するのが最も好ましいが, BOD 測定には 5 日間要 し,この場合実際的ではない。これに変わるものとし て， $\mathrm{O}_{2} \mathrm{Rr}$ レベルの測定により污泥の状態がいち早く 察知できるので記述する。

まず, ばっ気槽污泥について $\mathrm{O}_{2} \mathrm{Rr}$ を測定する。こ の值を（A）とする。次に，(A) を測定した污泥に生
排水（基質）を加え同様にして测定する。この值を （B）として (B/A) 比を求め，これより活性度を判定 して負荷量アップの基準にしている。通常, 運転時の 経験から，(A) が $40 \mathrm{ppm} / \mathrm{h}$ 以下であり（A が高い ことは BOD 負荷が高いことを意味する)，且つ， $\mathrm{B} / \mathrm{A}$ が 1.5 倍以上であれば污泥に問題ないとして $\mathrm{BOD}$ 負荷をアップする(水量の增量を行なう)。 (B/A) が低い時は (A) が非常に高い值 (BOD 負荷 が高い）と低い時であって, 基質を加えても $\mathrm{O}_{2} \mathrm{Rr} か ゙$ 上昇しない 2 ケースが考えられる。

(A) が高く（B/A）が低い（1.5以下）の場合は， $\mathrm{BOD}$ 負荷量が高いので減らすようなアクションをと らなければならない。最覀の状態は (A) が低く, 基 質を加えても $\mathrm{O}_{2} \mathrm{Rr}$ が上昇しないケースである。この 場合, 污泥が不活性化している状態（菌体が死诚）で あることを意味するので，このようにならない前に手 を打つ必要がある。

以上の上5に, $\mathrm{O}_{2} \mathrm{Rr}$ は長期停止後の BOD 負荷ア ップの指標になるばかりでなく, 日常の運転管理にお いても污泥の異常を迅速に察知できるので重要な管理 ポイントにしているが, 計装化できないのでこれに代 わる指標として酸化還元電位等で管理できないものか, 読者諸氏のご意見を承りたいところである。

\section{5. その他}

塩素系排水は $\mathrm{E}_{1}$ 排水と混合することによって有効 塩素は消費され幣害はないと述べたが, 操業スタート 時には工程が不安定になりやすく, 塩素の過剩添加か ら排水中の有効塩素が多くなり残塩素がばっ気槽に入 るおそれがあるので, チ才硫酸ソーダ等の添加設備を 完備しておくにこしたことはない。

長期休転後は前述したように, 一挙に全量処理する ことは好ましくないので, この間, 一部未処理で排出 されることになるので処理設備の計画段階で対策を検 討しておく必要がある。

当工場の場合は, この未処理水を加圧浮上処理装置 に導入し処理している。活性污泥装置をバイパスして 直接凝集沈殿処理を試みたが, 泡の発生が著しくこの 泡にフロックが付着しスカム状になって処理できる状 態ではなかった。このことからも, 凝集沈殿を活性污 泥処理の前にもってくることは好ましくない。

\section{6. まと め}

（1）処理状況を適確に把握するために機器の運転状況 をチェックすることは勿論のこと, 水量, $\mathrm{DO}, \mathrm{O}_{2}$ $\mathrm{Rr}$ などの計測及び水質分析は不可欠であるが，そ 
れほどシビヤなものではなく 1 日1回ぐらいでけ分 である。

（2）晒系排水の活性洁泥一凝沈処理は期待した成果を 収め得たが，しかし，発泡問題は意外と重大で消泡 剂が要ることもさることながら，機械ばっ気の場合 は泡だちが激しくなると擋拌效果が低下し，污泥の 沈降につながる危俛もあるので注意を要する。

(3) 凝讴一活性污泥処理のフローは, 凝沈単独処理が 可能かどらかを十分に碓琵して沃定する必要がある。

(4) 生物処理は中性付近で運転されるにもかかわらず 腐食性が非常に激しく, 消泡配管やレーキの材質を 娭討する必留がある。凝沈処理においても $\mathrm{pH} 6$ 付 近の運転であるが，レーキメカニズムは $2 \sim 3$ 年で
腐食し取り替えた経験がある。ポンプ関係も少なく とも SCS 1 ぐらいにはしたいものと思う。

（5）冬期休転中はばっ気槽の水温が低下し，スタート 時には立ち上がりを荤らせる結果になるので蒸気等 による加温対策も必要であるう。

(6) 最もやっかいな長期僖止時の運転管理については 一般テキストに畫いてあるような処置はとらていと れるものでなく，これまでの経験から 2 日ぐらいの 立ちにがりをみれば，1力月程度は基質補給なしで 維持できるのではないかと思われるが，スタートア ップ時のために凝沈や，浮上処理装置の能力は十分 見込んで対処する必要があろう。

\section{新刊紹 介 和漢紙 文献類聚 古代·中世編}

編者 関 義城, 発行所 思文閣, 定価 13,000円 B 5 判 356 頁

本書は扸利 48 年 5 月，関さんが自費出版された「江戸時代編」の峬妹篇である。

引用文献…日本の文献…古事記・日本書紀・万葉集・源氏物語・土佐日記・落䆶物語・枕草子・大鏡・

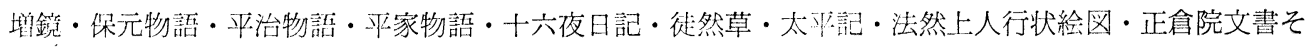
の他合部 257 。中国の文献…刲 40

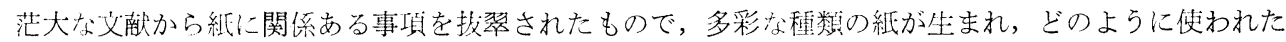
かをたどっている。背は紙は極めて貴重品であり，この紙を公家や武家等が大切に取扱った頃の姿が要領 を得た引用文によって明示されている。我々紙の同好の士は勿論, 歴史学・国文学・支那支学研究の人々 にもよい参考文献にちがいない。引用文献が極めて正確であるから莄古学・歴史学, 並に一般文学に於て

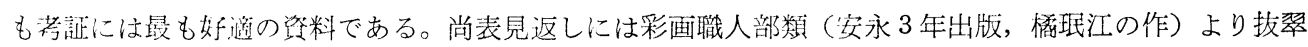
せる本邦紙すきの美人闵会（説明付），裹見返しには中国の紙すき䦷絵（フランス国立図書館所蔵，18世 紀後期，画家不明）上り抜翠せる中国の紙すき図会が記載されている。

\section{内容の一例}

〔日本書紀〕二十一 推古天自卷

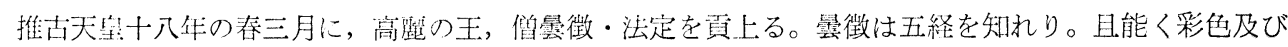

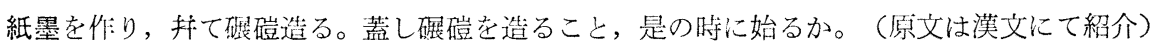

この記事が我国で最も古い製紙の記録である。

〔義経記】叫膊越の川状の事

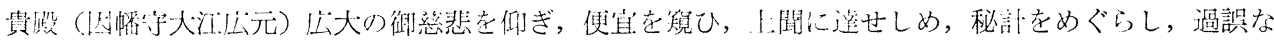

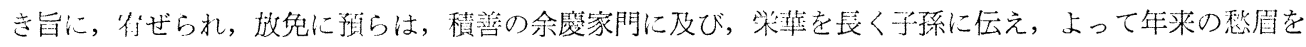
開き，一期の弃煷を得んことを書紙につくさず。

[太平記 然二 俊基被誅事

俊基县䋊を取り出し，頸のまはり押し拭ひ其紙を推し開いて辞世の頌を畫き給う。 